\title{
Reduction in fluid secretion by rat testis by drugs that block potassium channels
}

\author{
B. P. Setchell ${ }^{1 *}$, L. Plöen ${ }^{2}$ and E. M. Ritzen ${ }^{3}$ \\ ${ }^{1}$ Department of Animal Science, University of Adelaide, Waite Campus, Glen Osmond, SA 5064, \\ Australia; ${ }^{2}$ Department of Anatomy and Histology, Faculty of Veterinary Medicine, Swedish University \\ of Agricultural Science, Uppsala, Sweden; and ${ }^{3}$ Pediatric Endocrinology Unit, Karolinska Hospital, \\ Stockholm, Sweden
}

\begin{abstract}
The effect of two class III antiarrhythmic drugs (Almokalant, Astra-Hässle and Dofetilide, Pfizer) on fluid secretion by rat testes has been examined. Both drugs reduced fluid secretion, whether this was measured by the amount of rete testis fluid that could be collected $22 \mathrm{~h}$ after unilateral efferent duct ligation, or by the difference in mass between the ligated and unligated testes, or by the difference in amount of supernatant fluid after the parenchyma of the ligated and unligated testes had been dispersed and centrifuged. The secretion of potassium, calculated from the amount of potassium in the supernatant fluids from the ligated and unligated testes was also reduced by the drugs, whereas the secretion of androgen-binding protein and inositol was unaffected. The concentration of potassium in the secreted fluid, calculated from the amount and composition of the supernatant fluids, was not affected by treatment of the rats with Almokalant, but was increased in rats treated with Dofetilide and, in these, the concentration of sodium was reduced and that of magnesium and inositol was increased and the concentration of total protein was unaffected. The concentration of androgen-binding protein in secreted fluid was increased in rats treated with Almokalant, while the concentration of testosterone was unaffected. Histological examination of testes from treated rats revealed phagocytosis of stage 19 spermatids in tubules at stages VIII-IX after 2 days, at stages IX-XI after 4 days and at stages VIII-XIV after 7 days, apparently owing to an effect on spermiation. It appears that these drugs interfere with potassium-mediated fluid secretion by the testis, leading to the other changes seen.
\end{abstract}

\section{Introduction}

Class III antiarrhythmic drugs appear to affect the heart by blocking potassium channels (Colatsky and Follmer, 1990). Four types of potassium channel occur in a variety of tissues: voltage-activated, Ca-dependent, ATP-sensitive and receptormediated (Muniz et al., 1992, Ferrer et al., 1995), the last type including muscarinic-linked channels (Kurachi, 1995). However, there appears to be little information on their occurrence in the testis, except that voltage-activated channels do not appear to be present (Muniz et al., 1992). During the testing of a new Class III anti-arrhythmic drug, Almokalant (H234/09; Astra-Hässle, Mölndal), it was noticed that the testes of male rats became atrophied after prolonged treatment with the drug. Since potassium transport may be the basis for fluid secretion by the Sertoli cells in the testis (Waites and Gladwell, 1982; Hinton and Setchell, 1993), it is possible that the cause of this atrophy was an interference with potassium and fluid secretion by the Sertoli cells. This possibility was tested and evidence for the involvement of potassium transport in fluid secretion in the

*Correspondence

Revised manuscript received 13 August 1997 testis was obtained by studying the effect of short-term administration of this drug or another Class III antiarrhythmic drug (Dofetilide, Pfizer, New York) on testicular fluid secretion and composition in rats.

\section{Materials and Methods}

\section{Experiment 1}

A total of 48 Sprague-Dawley rats, purchased from Alab, Stockholm, weighing between 250 and $350 \mathrm{~g}$ at the start of the experiment, were used. They were divided randomly into six groups of eight rats each, and housed four to a cage in an animal house at the Karolinska Hospital. They were fed on diet R36 (Ewos, Stockholm) with water available ad libitum. The rats were dosed by gavage using an infant feeding tube each morning between $08: 30 \mathrm{~h}$ and $09: 30 \mathrm{~h}$ for 2,4 or 7 days either with Almokalant $\left(500 \mu \mathrm{mol} \mathrm{kg}{ }^{-1}\right.$ body mass using a solution of $100 \mu \mathrm{mol} \mathrm{ml}{ }^{-1}$ in citrate buffer, $\mathrm{pH} 5.0$ ) or with the same volume of buffer solution. The 2 day groups were done first, the 4 day groups started 5 days later, and the 7 day groups 
after a further 8 days, so that there were intervals of 8 and 10 days between the samplings. On the last day of treatment, between 11:00 $\mathrm{h}$ and 13:00 h, each rat was anaesthetized with avertin $\left(8 \mathrm{ml} \mathrm{kg}^{-1}\right.$ body mass i.p. of a solution made by dissolving $1 \mathrm{~g} \mathrm{2,2,2-tribromoethanol} \mathrm{and} 3 \mathrm{ml}$ tert-amyl alcohol in $1 \mathrm{ml}$ water, diluting with $4 \mathrm{ml}$ ethanol and then making to $50 \mathrm{ml}$ with saline), and the efferent ducts of the left testis ligated as described by Setchell (1970). Next day, beginning at 09:00 h, that is, $22 \mathrm{~h}$ after efferent duct ligation, the rats were anaesthetized with pentobarbitone sodium $\left(50 \mathrm{mg} \mathrm{kg}^{-1}\right.$ body mass i.p.), and the left testis was exposed through a scrotal skin incision. Rete testis fluid $(20-150 \mu \mathrm{l})$ was collected into a haematocrit tube as described by Setchell and Main (1975); the volume was recorded from the length of the fluid column and the sample diluted with three volumes of saline before centrifugation at $1000 \mathrm{~g}$ for $5 \mathrm{~min}$ to remove the spermatozoa. The right testis was exposed and blood was collected from a testicular vein as described by Galil and Setchell (1988). A second heparinized blood sample was then collected from the posterior vena cava, both testes were removed and the animal was killed. The blood samples were centrifuged at $3000 \mathrm{~g}$ for $20 \mathrm{~min}$ and plasma was separated. The testes were weighed, the capsules were opened and the parenchyma from each testis were separated and weighed. Approximately $100 \mathrm{mg}$ of parenchyma was then removed from one end of the unligated testis and placed into glutaraldehyde fixative for subsequent histology. The remainder of the unligated testis parenchyma and all the ligated testis parenchyma were then extruded through 21 gauge needles with $5 \mathrm{ml}$ syringes into pre-weighed Eppendorf tubes, which were then centrifuged at $10000 \mathrm{~g}$ for 15 min to yield a fluid supernatant and cell sediment. The fluid was separated and weighed and the mass of the cell sediment obtained by reweighing the tube. All samples were then stored at $-20^{\circ} \mathrm{C}$ until they were analysed. The supernatant fluids, diluted rete testis fluid (pooled from more than one animal if the volumes were less than the $200 \mu \mathrm{l}$ required for analysis) and the peripheral blood samples were analysed for potassium by flame photometry at the Clinical Chemistry Laboratory of the Löwenströmska Sjukhuset. Supernatant fluids, testicular venous and peripheral blood samples were analysed for testosterone by radioimmunoassay using a DPC Coat-a-count kit (Diagnostic Products Corporation, Los Angeles) at the Karolinska Hospital. Androgen-binding protein (ABP) in the supernatant fluid was estimated by the method of Ritzen et al. (1974).

Fluid secretion was estimated in two ways. Total secreted fluid (that is, tubular and rete fluids) was determined from the mass difference between the two testes plus the amount of RTF collected. Additional or secreted tubular fluid (STF, which has been shown to be largely derived from seminiferous tubule luminal fluid; Setchell et al, 1996) was estimated from the difference between the amounts of supernatant fluid collected from the decapsulated ligated testes (LF) and unligated testes (UF), respectively, after a correction had been made for the amount of unligated testis removed for histology. The amount of potassium and ABP secreted was determined by subtracting the amounts in the supernatant fluid from the unligated testis from the amounts in the fluid from the ligated testis. The concentration in the STF was calculated by dividing the amount secreted by the volume of additional secreted tubular fluid.
The testis samples fixed in glutaraldehyde were processed for light microscopy by embedding in Historesin ${ }^{\hat{\mathbf{R}}}$, a glycol methacrylate, sectioning at $2 \mu \mathrm{m}$ and staining with haematoxylin and periodic acid-Schiff. The sections were evaluated under an oil immersion objective ( $\times 60$, NA 1.3$)$.

\section{Experiment 2}

The procedures adopted in this experiment were essentially the same as in Expt 1, except that instead of Almokalant, the drug Dofetilide (Pfizer) was used at a dosage of $50 \mu \mathrm{mol} \mathrm{kg}$ body mass, using a solution of $7.5 \mu \mathrm{mol} \mathrm{ml}^{-1}$ in citrate buffer, $\mathrm{pH} 4.8$, and the drug or buffer alone was administered by gavage at 17:00 h each day, with the last dose after the efferent ducts had been ligated. The experiment was performed in two replicates, with half the animals from all groups sampled on one day and the other half on the next day. Rats were DA strain from the Central Animal House of the University of Adelaide and weighed between 151 and $264 \mathrm{~g}$ (mean $231 \pm 4.2 \mathrm{~g}$ ) at the start of the trial. They were held in the animal house of the Department of Animal Science, which is maintained at $21^{\circ} \mathrm{C}$ with lights on at 07:00 h and off at 19:00 h, and fed Joint Stock Ration (Milling Industries, Adelaide) with water available ad libitum. Samples were collected as described previously. Potassium, sodium and magnesium were estimated by atomic absorption at Vetlab, Adelaide; inositol was estimated by gas liquid chromatography according to the method of Blakeney et al. (1982, 1983); and total protein was estimated by the method of Bradford (1976). The amounts of sodium, magnesium, inositol and protein secreted and their concentrations in the STF were determined as for potassium in Expt 1. No estimations of testosterone or ABP were made in this experiment, because no changes in testosterone were seen in the first experiment and ABP analyses were not available in Adelaide.

\section{Statistical methods}

Data were analysed by two-way (drug treatment or control and time of treatment) analysis of variance (Superanova, Abacus Concepts, Berkeley, CA), followed by $t$ test for individual groups. The data on concentration differences between ligated and unligated testes were analysed by paired $t$ test.

\section{Results}

\section{Fluid secretion}

Both drugs produced an obvious and highly significant effect on fluid secretion by the testis, whether this was estimated from the difference in mass after efferent duct ligation of the whole testis plus the volume of RTF collected, the difference in the amounts of supernatant fluid between the ligated and unligated testes, or the volume of RTF actually collected (Tables I and 2). No attempt was made to adjust the values for differences in testis mass, since there appears to be no correlation between fluid secretion and testis mass in adult rats (Hinton and Setchell, 1993). The effect on the volume of RTF 
Table 1. Secretion of fluid, potassium and androgen-binding protein by the testes of Almokalant-treated and control rats (means \pm SEM)

\begin{tabular}{|c|c|c|c|c|c|c|c|}
\hline \multirow[b]{2}{*}{ Days of treatment $(n)$} & \multicolumn{3}{|c|}{ Almokalant } & \multicolumn{3}{|c|}{ Control } & \multirow{2}{*}{$\begin{array}{c}P \text { versus } \\
\text { control }\end{array}$} \\
\hline & $2(8)$ & $4(8)$ & $7(6)$ & $2(7)$ & $4(8)$ & $7(7)$ & \\
\hline Total fluid & $338 \pm 30$ & $354 \pm 30^{* *}$ & $423 \pm 50$ & $422 \pm 34$ & $481 \pm 27$ & $458 \pm 40$ & 0.003 \\
\hline RTF & $41 \pm 7.4^{*}$ & $45 \pm 4.5^{* * *}$ & $54 \pm 12.3$ & $84 \pm 16$ & $90 \pm 8.8$ & $52 \pm 7.0$ & 0.0009 \\
\hline STF & $208 \pm 10.1^{* *}$ & $208 \pm 18.5^{* *}$ & $277 \pm 21.3$ & $262 \pm 13.4$ & $272 \pm 15.9$ & $334 \pm 32.3^{+\dagger \dagger}$ & 0.0011 \\
\hline UF & $220 \pm 12.4$ & $262 \pm 8.6$ & $303 \pm 8.5$ & $220 \pm 13.7$ & $272 \pm 7.2$ & $320 \pm 13.3^{+\dagger \dagger}$ & 0.292 \\
\hline $\mathrm{K}^{+}$secretion & $9.7 \pm 0.7^{*}$ & $10.1 \pm 1.1$ & $12.2 \pm 1.6$ & $13.1 \pm 1.5$ & $13.3 \pm 1.1$ & $16.5 \pm 1.7$ & 0.0015 \\
\hline ABP secretion & $76.7 \pm 3.9$ & $56.0 \pm 9.8$ & $63.3 \pm 10.8$ & $61.7 \pm 7.9$ & $74.7 \pm 9.2$ & $57.2 \pm 8.0$ & 0.90 \\
\hline Testis mass (mg) & $1460 \pm 41$ & $1610 \pm 41$ & $1740 \pm 33$ & $1490 \pm 29$ & $1650 \pm 28$ & $1820 \pm 44^{\dagger+\dagger}$ & 0.100 \\
\hline Body mass (g) & $267 \pm 2.7$ & $322 \pm 3.5$ & $371 \pm 5.0^{*}$ & $275 \pm 2.9$ & $323 \pm 4.5$ & $385 \pm 3.9^{+\dagger t}$ & 0.376 \\
\hline
\end{tabular}

Total fluid: difference in testis mass ( $\mathrm{mg}$ ) between ligated and unligated testes + volume of rete testis fluid collected ( $\mu \mathrm{l}$ ); RTF: volume of rete testis fluid collected $(\mu \mathrm{l})$; STF: amount of seminiferous tubule fluid secreted (difference in amount of supernatant fluid between ligated and unligated testes (mg)); UF: amount of supernatant fluid from unligated testis (mg); $\mathrm{K}^{+}$and $\mathrm{ABP}$ secretion (nmol and pmol per testis per $22 \mathrm{~h}$, respectively) are calculated as described in the text. ${ }^{*} P<0.05, * * P<0.01,{ }^{* * *} P<0.001$ significantly different from corresponding control by $t$ test after ANOVA.

${ }^{++\dagger} P<0.001$ significant difference between 2-, 4- and 7-day groups by ANOVA.

Table 2. Secretion of fluid, potassium and other ions and inositol by the testes of Dofetilide-treated and control rats (means \pm SEM)

\begin{tabular}{|c|c|c|c|c|c|c|c|}
\hline \multirow{2}{*}{$\begin{array}{l}\text { Days of } \\
\text { treatment }(n)\end{array}$} & \multicolumn{3}{|c|}{ Dofetilide } & \multicolumn{3}{|c|}{ Control } & \multirow{2}{*}{$\begin{array}{l}P \text { versus } \\
\text { control }\end{array}$} \\
\hline & $2(8)$ & $4(6)$ & $7(6)$ & $2(8)$ & $4(8)$ & $7(8)$ & \\
\hline Total fluid & $207 \pm 20 * * *$ & $153 \pm 17^{* * *}$ & $156 \pm 15^{* * *}$ & $330 \pm 21$ & $356 \pm 20$ & $259 \pm 14^{\dagger \dagger}$ & 0.0001 \\
\hline RTF & $1.1 \pm 0.8 * * *$ & $0.2 \pm 0.2 * * *$ & $1.5 \pm 0.8 * * *$ & $22.8 \pm 6.8$ & $36.5 \pm 5.2$ & $38.1 \pm 5.1$ & 0.0001 \\
\hline STF & $124 \pm 9.3^{* * *}$ & $105 \pm 12.2^{* * *}$ & $81 \pm 10.8^{* * *}$ & $255 \pm 13.0$ & $256 \pm 10.4$ & $180 \pm 8.1^{+\dagger \dagger}$ & 0.0001 \\
\hline UF & $1.52 \pm 3.7^{*}$ & $150 \pm 11.0^{* *}$ & $141 \pm 3.8^{* *}$ & $176 \pm 9.2$ & $201 \pm 10.3$ & $182 \pm 13.0$ & 0.0001 \\
\hline $\mathrm{K}^{+}$secretion & $8.3 \pm 1.0^{*}$ & $6.1 \pm 0.9^{* *}$ & $4.8 \pm 0.6^{* *}$ & $13.3 \pm 1.4$ & $10.3 \pm 0.9$ & $7.8 \pm 0.6^{+++}$ & 0.0002 \\
\hline $\mathrm{Na}^{+}$secretion & $10.8 \pm 0.94^{* * *}$ & $10.0 \pm 0.88^{* * *}$ & $7.8 \pm 0.86^{* * *}$ & $28.3 \pm 1.18$ & $27.5 \pm 2.13$ & $20.2 \pm 0.88^{\dagger+\dagger}$ & 0.0001 \\
\hline $\mathrm{Mg}^{2+}$ secretion & $0.37 \pm 0.06^{*}$ & $0.37 \pm 0.10$ & $0.21 \pm 0.04^{* *}$ & $0.61 \pm 0.06$ & $0.45 \pm 0.04$ & $0.51 \pm 0.05$ & 0.0005 \\
\hline Inositol secretion & $678 \pm 61$ & $591 \pm 30$ & $476 \pm 56$ & $686 \pm 80$ & $549 \pm 44$ & $522 \pm 46^{+\dagger}$ & 0.94 \\
\hline Testis mass & $1003 \pm 24$ & $955 \pm 35 * *$ & $908 \pm 43$ & $1045 \pm 28$ & $1102 \pm 23$ & $1022 \pm 41$ & 0.0012 \\
\hline Body mass & $239 \pm 6.9$ & $215 \pm 12.6$ & $213 \pm 7.4$ & $241 \pm 3.4$ & $228 \pm 5.3$ & $193 \pm 13.2^{+\dagger \dagger}$ & 0.82 \\
\hline
\end{tabular}

Total fluid: difference in testis mass (mg) between ligated and unligated testes + volume of rete testis fluid collected ( $\mu \mathrm{I}$ ); RTF: volume of rete testis fluid collected ( $\mu l)$; STF: amount of seminiferous tubule fluid secreted (difference in amount of supernatant fluid between ligated and unligated testes (mg)); UF: amount of supernatant fluid from unligated testis $(\mathrm{mg}) ; \mathrm{K}^{+}$secretion ( $\mathrm{nmol}$ per testis per $22 \mathrm{~h}$ ) and $\mathrm{Na}^{+}, \mathrm{Mg}^{2+}$ and inositol secretion (nmol per testis per $22 \mathrm{~h}$ ) are calculated as described in the text.

${ }^{*} P<0.05,{ }^{* *} P<0.01,{ }^{* * *} P<0.001$ significantly different from corresponding control by $t$ test after ANOVA.

${ }^{\dagger \dagger} P<0.01,{ }^{\dagger+\dagger} P<0.001$ significant difference between 2-, 4- and 7-day groups by ANOVA.

which it was possible to collect was much more obvious with Dofetilide than with Almokalant. With Almokalant, the changes in fluid secretion were not associated with any change in the amount of supernatant fluid from the unligated testis, but with Dofetilide, this value was also significantly reduced in the treated animals.

\section{Composition of secreted and other fluids}

The reduced fluid secretion was associated with a reduction in the amount of potassium secreted into the tubular fluid in the treated animals in both experiments (Tables 1 and 2), although there were no differences due to treatment with Almokalant in the concentrations of potassium in the additional STF, or the UF or LF (Table 3). Treatment with Almokalant had no effect on the concentration of potassium in rete testis fluid ( $\left.12.30 \pm 0.22 \mathrm{mmol} \mathrm{I}^{-1} ; n=24\right)$. In Expt 2, the concentration of potassium in the STF was similar in the control animals but higher in the Dofetilide-treated animals, and there was a similar difference for the concentrations in UF and LF, with again the LF having a lower concentration than the UF. Insufficient rete testis fluid could be collected from the Dofetilide-treated rats for potassium analysis. In both experiments, the concentration of potassium in the STF was highly correlated with the concentrations in the LF $(P<0.001, r=0.806$ and 0.763 , respectively, for Expts 1 and 2) but was not significantly correlated with the concentration in the UF $(P=0.247$ and $0.093, r=0.178$ and 0.260 , respectively).

The secretion of sodium and magnesium was similarly reduced in the Dofetilide-treated rats (Table 2) and, like 
Table 3. The composition of additional secreted fluid (STF) and supernatant fluid from unligated and ligated testes (UF and LF) from control rats (C) or rats treated (T) for 2, 4 or 7 days with Almokalant (A) or Dofetilide (D) (means \pm SEM)

\begin{tabular}{|c|c|c|c|c|c|}
\hline & Drug & Group & STF & UF & LF \\
\hline \multirow[t]{3}{*}{$\mathrm{K}\left(\mathrm{mmol} \mathrm{l^{-1 } )}\right.$} & A & $C+T$ & $48.6 \pm 1.7^{* * *}$ & $76.5 \pm 1.14$ & $62.6 \pm 0.98^{* * *}$ \\
\hline & $\mathrm{D}$ & C & $44.9 \pm 1.98^{* * *}$ & $84.8 \pm 1.15$ & $63.0 \pm 0.99 * * *$ \\
\hline & & $\mathrm{T}$ & $60.1 \pm 2.61^{\dagger+\dagger}$ & $96.5 \pm 1.38^{++\hbar}$ & $81.6 \pm 0.96^{++\dagger}$ \\
\hline \multirow[t]{2}{*}{$\mathrm{Na}\left(\mathrm{mmol} \mathrm{l} \mathrm{l}^{-1}\right)$} & $\mathrm{D}$ & $\mathrm{C}$ & $110.2 \pm 2.6^{* * *}$ & $66.6 \pm 0.66$ & $90.3 \pm 1.2^{* * *}$ \\
\hline & & $\mathrm{T}$ & $94.6 \pm 3.8^{\dagger+}$ & $56.9 \pm 1.5^{++t}$ & $71.4 \pm 1.1^{* * *}$ \\
\hline \multirow[t]{2}{*}{$\mathrm{Mg}\left(\mathrm{mmol} 1^{-1}\right)$} & $\mathrm{D}$ & $\mathrm{C}$ & $2.29 \pm 0.6^{* * *}$ & $4.10 \pm 0.12$ & $3.05 \pm 0.065^{* *}$ \\
\hline & & $\mathrm{T}$ & $3.21 \pm 0.24^{++t}$ & $4.60 \pm 0.12^{\dagger+}$ & $3.96 \pm 0.089^{++\dagger}$ \\
\hline \multirow[t]{2}{*}{ ABP (fmole $\mathrm{mg}^{-\mathrm{I}}$ ) } & A & C & $228 \pm 17 * * *$ & $119 \pm 8.2$ & $177 \pm 9.1 * * *$ \\
\hline & & $\mathrm{T}$ & $296 \pm 23^{+}$ & $112 \pm 6.8$ & $198 \pm 10.6^{* *}$ \\
\hline \multirow[t]{2}{*}{ Protein (mg ml-1) } & $\mathrm{D}$ & $\mathrm{C}$ & $2.7 \pm 2.4 * * *$ & $43.1 \pm 2.2$ & $21.5 \pm 0.6 * * *$ \\
\hline & & $\mathrm{T}$ & $-7.3 \pm 7.4$ & $59.2 \pm 4.6^{\dagger \dagger \dagger}$ & $32.8 \pm 1.4^{\dagger \dagger \dagger}$ \\
\hline \multirow[t]{2}{*}{ Inositol $\left(\mu\right.$ mole $\left.\mathrm{ml}^{-1}\right)$} & $\mathrm{D}$ & C & $2.66 \pm 0.12$ & $2.52 \pm 0.12$ & $2.93 \pm 0.21$ \\
\hline & & $\mathrm{T}$ & $6.24 \pm 0.60^{++t}$ & $2.63 \pm 0.07$ & $4.14 \pm 0.16^{\dagger+\dagger}$ \\
\hline Testosterone $\left(\mathrm{nmol} \mathrm{l}^{-1}\right)$ & A & $C+T$ & $154 \pm 7.6$ & $132 \pm 6.3$ & $142 \pm 4.5$ \\
\hline
\end{tabular}

$n=22$ for control and treated groups in the Almokalant experiment and $n=20$ for the control and $n=24$ for the treated groups in the Dofetilide experiment.

${ }^{* *} P<0.01,{ }^{* * *} P<0.001$ significantly different from corresponding UF.

${ }^{+} P<0.05,{ }^{++} P<0.01,{ }^{+*+} P<0.001$ significantly different from corresponding control.

$C+T$ : control and treated data were pooled when there were no significant differences between them.

potassium, the concentration of magnesium was higher in the treated animals in the STF, UF and LF, whereas the reverse was the case with sodium. Both sodium and magnesium concentrations in STF were highly correlated with those in LF $(P<0.001, r=0.643$ and 0.659 , respectively), but sodium in STF was not correlated with the concentration in UF $(P=0.643, r=0.033)$, while there was a weak correlation of magnesium concentration in STF with that in UF $(P=0.02$, $r=0.344$ ). The concentrations in vena cava blood plasma of potassium (3.60 \pm 0.076 in Expt 1 and $5.60+0.087 \mathrm{mmol} \mathrm{l}^{-1}$ in Expt 2), sodium (145 $\pm 1.80 \mathrm{mmol} \mathrm{l}^{-1}$ ) and magnesium $\left(0.714 \pm 0.0090 \mathrm{mmol}^{-1}\right)$ were not affected by treatment.

In contrast to the effects on potassium secretion, there was no effect of Almokalant on the amount of ABP secreted into the tubular fluid (Table 1), because a higher concentration in STF fully compensated for the smaller amount of fluid secreted. There were no effects of treatment on the concentrations in UF and LF, while the difference between the two fluids was highly significant $(P<0.001)$. As with the ions studied, the concentration of ABP in STF in Expt 1 was correlated with that in LF, but not with the concentration in UF $(P<0.001, r=0.95$, and $P=0.659, r=0.099$, respectively). Similarly, in Expt 2, there was no effect of treatment on the amount of inositol secreted (Table 2), since the concentration in STF compensated for the smaller amount of fluid secreted. A concentration difference was also seen in LF, but not in UF and, again, the concentration in STF was highly correlated for control, treated and pooled data with that in LF $(P<0.001, r=0.76,0.75$ and 0.87 , respectively) but not with that in UF $(P=0.59,0.62$ and $0.46, r=0.12,0.12$ and 0.11 , respectively). Treatment with Dofetilide caused increases in the concentration of total protein in supernatant fluid from both unligated and ligated testes. The calculated concentration of protein in STF was not affected by treatment, but it must be said that neither of these values are significantly different from zero. However, there are difficulties with this method in estimating accurately the concentration of a substance which is present in STF at very much lower concentrations than in the supernatant fluids.

The concentrations of testosterone in STF, UF, LF, testicular venous $\left(34.4 \pm 6.8 \mathrm{nmol} \mathrm{I}^{-1}\right)$ and vena caval blood plasma $\left(14.5+3.1 \mathrm{nmol} 1^{-1}\right)$ were not affected by treatment with Almokalant. There were significant correlations between testicular venous and vena caval blood plasma $(P=0.002$, $r=0.479)$ and between STF and LF concentrations $(P=0.001$, $r=0.700$ ), but not between STF and UF concentrations $(P=0.98, r=0.004)$.

\section{Testis and body masses}

The testis mass was not significantly affected by treatment with Almokalant (Table 1), but was reduced in the animals treated with Dofetilide (Table 2). However, the animals in the three treatment groups in Expt I were studied at different times, and both testis mass and body mass increased with time. The cell fraction made up about $80 \%$ of the parenchymal mass, and this proportion was slightly, but significantly, higher $(P=0.001)$ in the Dofetilide-treated rats $(82.44 \pm 0.35$ versus $80.48 \pm 0.40 \%$ ). In contrast with earlier observations (Setchell et al., 1976, 1996), probably because of the larger numbers of animals involved in the present study, the mass of the cell fraction was slightly, but significantly, greater in the ligated testes, but neither drug treatment had any effect on this difference (Expt 1: 78.2 \pm 7.4 ; Expt 2: $85.5 \pm 7.9 \mathrm{mg}$ ). There also appeared to be a small, but significant, effect of Almokalant on body mass (Table 1), but the animals in Expt I were not individually weighed before the beginning of treatment. In Expt 2, treatment had no effect on body mass (Table 2). 


\section{Histology}

All control testes appeared normal (Fig. Ia). In the testes of rats treated with either drug, step 19 spermatids phagocytosed by Sertoli cells were frequently observed, but there was a substantial variation in the severity of the damage among treated animals and also within individual testes. In the Almokalant-treated rats, only four showed limited alterations at 2 days but, after 4 days, all rats showed minor changes, and even after 7 days, there were only a few phagocytosed stage 19 spermatids apparent (Fig. 1c). In the animals treated with Dofetilide, the number of phagocytosed stage 19 spermatids in late stages VIII-IX were somewhat higher than in those treated with Almokalant and, after treatment for 4 days, they were found in tubules in stages IX-XI. After treatment with Dofetilide for 7 days, there were pronounced alterations in some rats (Fig. Ib, d), with many phagocytosed stage 19 spermatids in tubules at stages VIII-I.

\section{Discussion}

It is clear from these results that treatment of rats with either of two drugs that block potassium channels caused a profound decrease in fluid secretion by the testes, presumably by affecting the Sertoli cells. This effect was apparent with as little as two daily treatments, and did not appear to become more pronounced with prolonged treatment. Therefore, it would be interesting to examine the effects of single doses of these and similar drugs. The amounts of fluid secreted by the control testes in the present experiment are very similar to those reported earlier (Total fluid: $400-500 \mathrm{mg}$ per testis per $16 \mathrm{~h}$, see Hinton and Setchell, 1993; STF: $270 \mathrm{mg}$ per testis per $16 \mathrm{~h}$, Setchell et al., 1976; 345, 309 and $349 \mathrm{mg}$ per testis per $20 \mathrm{~h}$ in three separate experiments, Setchell et al., 1996).

The only other treatments to cause such a profound and sudden decrease in fluid secretion are an intratesticular injection of colchicine or treatment of young rats with di- $n$-pentylphthalate. A dose of $4 \mu \mathrm{g}$ colchicine produced a $30 \%$ decrease within the next $16 \mathrm{~h}$, and $40 \mu \mathrm{g}$ almost stopped fluid production, measured in the same way as in the present study (Allard et al., 1993). Exposure of isolated tubules to colchicine or an inhibitor of protein synthesis (Brefeldin A) inhibited fluid secretion in vitro, as measured by the rate of movement of a luminal oil droplet (Richburg et al., 1994) and, in vivo, there was complete inhibition of fluid secretion by the testes beginning $\mathrm{I} \mathrm{h}$ after exposure of immature rats to $2.2 \mathrm{~g} \mathrm{di}-n$ pentylphthalate $\mathrm{kg}^{-1}$ (Gray and Gangolli, 1986). Other treatments had effects only after prolonged treatment. For example, the addition of 2,5-hexanedione to the drinking water of rats for 5 weeks initially had no effect on fluid secretion, although after about 4 weeks, fluid secretion fell by approximately $50 \%$, and remained depressed for several weeks after the end of treatment (Johnson et al., 1991; Richburg et al., 1994). Both colchicine and 2,5-hexanedione affect microtubule function, but there seems to be no evidence that they affect potassium secretion, or that the drugs used in the present study affect the microtubules. Other drugs that reduced fluid secretion are inhibitors of carbonic anhydrase, with metabolic alkalosis having a similar effect (Setchell and Brown, 1972).
In the Almokalant-treated rats, the decrease in fluid secretion was accompanied by a reduced secretion of potassium, but no change in the concentrations of potassium in the various testicular fluids, suggesting that the drug was acting specifically on potassium transport, and that the effects on fluid movement were secondary. With Dofetilide, potassium secretion was also reduced, but in contrast to the effects of Almokalant, the concentrations of potassium were increased in testicular fluids from the treated rats, suggesting that the drug was having effects on fluid secretion other than those mediated by potassium. While the changes in magnesium transport and concentrations are similar in nature to those for potassium, the amounts of magnesium present in the fluids make it unlikely that magnesium is the driving force behind much of the secretion. Sodium secretion was also reduced by Dofetilide, and the changes in sodium concentrations mirrored those in potassium, indicating that sodium may be moving passively down its electrochemical gradient.

The secretion of neither ABP nor inositol is reduced by treatment with the potassium channel blockers. This finding suggests that the secretion of these two substances by the Sertoli cells (Robinson and Fritz, 1979; Ritzen et al., 1981) is not linked to fluid production. It is a pity that because the two drugs were studied at different times in different countries, different strains of rat were used and both markers could not be measured in both experiments. In phthalate-treated rats, both fluid and $A B P$ secretion by the testes are reduced (Gray and Gangolli, 1986).

The concentrations of potassium and sodium in the additional STF, obtained in the present experiments by the 'difference' technique, are very similar to those found in micropuncture samples of seminiferous tubule fluid (50 and $108 \mathrm{mmol} \mathrm{l}^{-1}$, Tuck et al., 1970; 46 and $110 \mathrm{mmol} \mathrm{l}^{-1}$, Levine and Marsh, 1971; 40 and $135 \mathrm{mmol} \mathrm{l}^{-1}$, Jenkins et al., 1980). However Jenkins et al. (1980) also give values for magnesium $\left(1.19 \mathrm{mmol} \mathrm{I}^{-1}\right)$ that are approximately $50 \%$ of those reported here. The concentrations of potassium in the RTF are very similar to earlier values for fluid collected by a slightly different technique (14 mmol I-1, Tuck et al., 1970). The concentrations of inositol reported here are also very similar to those for micropuncture fluid (1.83 mmol $\mathrm{l}^{-1}$. Hinton et al., 1981) and for earlier estimates with the difference technique as used in the present study $\left(2.07 \mathrm{mmol} \mathrm{I}^{-1}\right.$, Setchell et al., 1976). The concentration of ABP in STF reported here is also very similar to that found by a similar analytical method for RTF $(180 \mathrm{pmol}$ $\mathrm{ml}^{-1}$, Ritzen et al., 1981), but rather higher than those reported in STF collected by micropuncture and a modification of the present technique, analysed by radioimmunoassay $(61$ and $44 \mathrm{pmol} \mathrm{ml}^{-1}$. Turner et al., 1984). The concentration of total protein in STF was similar to the value reported for samples collected by micropuncture $\left(5.4 \mathrm{mg} \mathrm{ml}^{-1}\right.$, Setchell et al., 1976; Hinton and Keefer, 1983) and is much lower than that reported by Turner et al. (1984) $\left(27.5 \mathrm{mg} \mathrm{ml}^{-1}\right.$ ). The present values are quite variable, and are in fact not significantly different from zero; they are subject to considerable error because we were trying to estimate a low concentration by measuring the difference between two fluids each of which contained high concentrations of protein. However, these results do indicate that Turner's technique suffers from some major defects, and is clearly not as satisfactory as that validated here. 

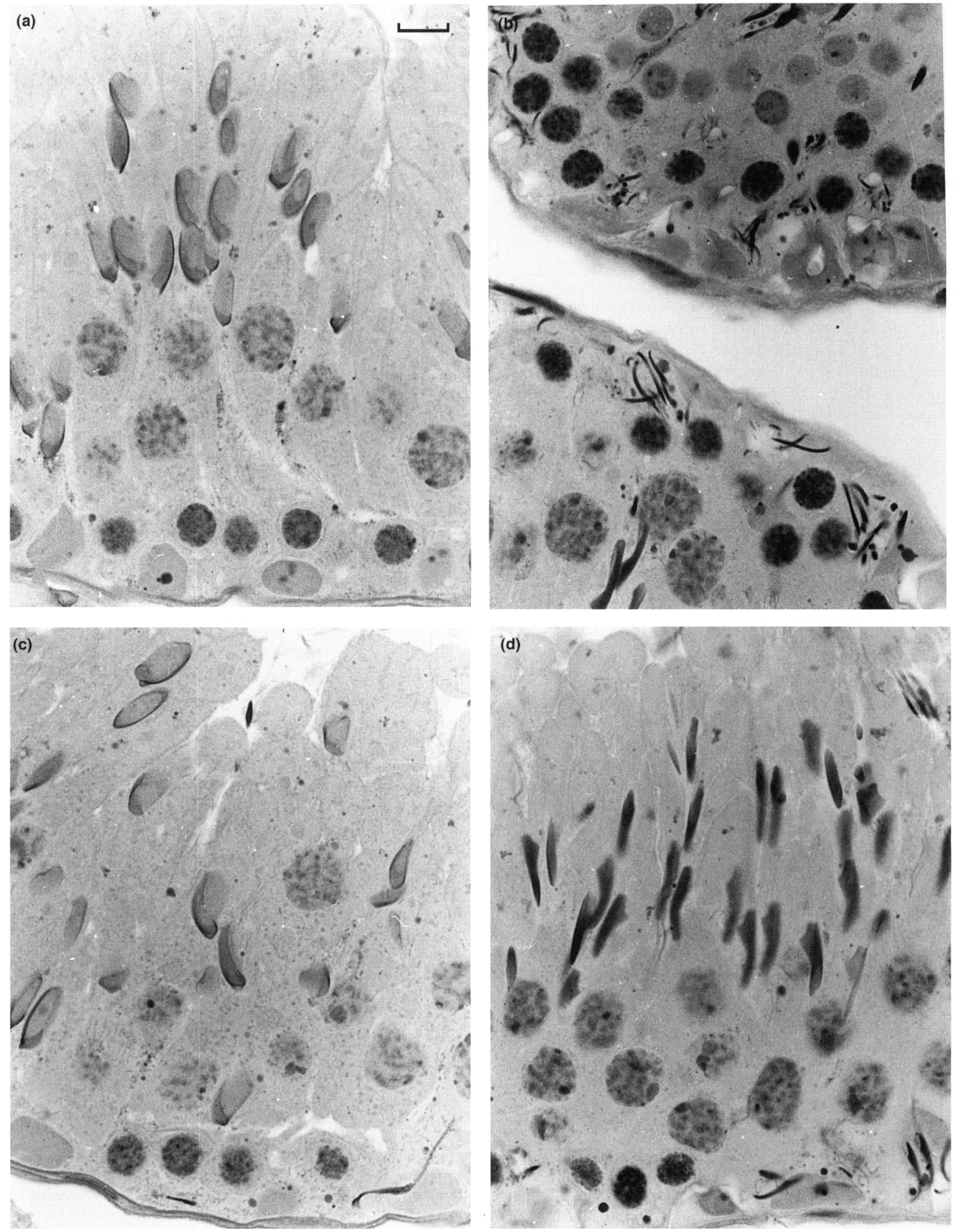

Fig. 1. (a) Section of a control rat testis, showing a normal seminiferous tubule at stage $X$ of the spermatogenic cycle. (b, d) Sections of testes from rats treated for 7 days with Dofetilide; (b) shows parts of two tubules, the upper at stage I and the lower at stage XIII, with extensive phagocytosis of step 19 spermatids; (d) shows a tubule at stage XI, also showing some phagocytosis of step 19 spermatids. (c) Section of a testis of rat treated for 7 days with Almokalant, with a tubule at stage $X$, showing a smail amount of phagocytosis of step 19 spermatids. Scale bar represents $10 \mu \mathrm{m}$. 
Nevertheless, Turner et al. (1984) found very similar concentrations of testosterone in STF $\left(168 \mathrm{nmol} \mathrm{l^{-1 }}\right.$ obtained by micropuncture; $174 \mathrm{nmol} 1^{-1}$ for fluid obtained by a modification of the present technique) as did our earlier studies using the difference technique (Setchell et al., 1978, $174 \mathrm{nmol}$ $\left.1^{-1}\right)$. However, Davies et al. (1978) reported that the concentrations of testosterone in testicular venous blood, as well as from UF and LF, can vary widely among groups of rats.

The histopathological findings of phagocytosed stage 19 spermatids in rats treated with Almokalant or Dofetilide are consistent with an effect on the Sertoli cells, since failure of sperm release in tubules at stage VIII of the cycle is a common finding when these cells are affected (Russell et al., 1990). Similar changes had been observed in a previous study, when rats were given twice the present dose $(1000 \mu \mathrm{mol}$ Almokalant $\mathrm{kg}^{-1}$ for up to 12 days). After 2 and 4 days, there were only minor changes but, after 7 and 12 days, most tubules were affected. In fact, in two rats treated at the higher dose for 7 days, there were severe changes in almost all tubules, and primary spermatocytes and round spermatids were also affected (L. Plöen, unpublished), an effect that could have been mediated through the Sertoli cells. The stages at which phagocytosed spermatids could be seen (tubules at stage VIII after treatment for 2 days, at stage IX-XI after 4 days and at stages VIII-I after 7 days) suggest that the effects of these drugs are quite rapid, and that they act on spermiation. The time from spermiation (end of stage VIII) to stage I is 4.5-5.5 days, and hence the effect may be limited to sperm release. The observation that there are more phagocytosed spermatids after 7 days than at the earlier times suggests that the effect may be progressive, and this is supported by the results of earlier experiments with a higher dose rate for up to 12 days (L. Plöen, unpublished), in which spermatocytes and spermatids were also affected, presumably these changes are also mediated by an effect on the Sertoli cells. The large variation in severity of the effect among animals, and within the testis, suggests that the dose was near the minimum producing morphological changes.

In conclusion, these studies validate the difference technique for estimating the composition of seminiferous tubule fluid and support the suggestion that fluid secretion by the testis is linked to potassium secretion. If the results of the present short-term experiments can be extrapolated to long-term treatment, the atrophy of the testis seen in rats treated with anti-arrhythmic drugs may be explained by an interference by the drug with potassium secretion, and hence fluid secretion.

The authors thank B. Fröysa for the ABP analyses, R. Fishlock for the inositol analyses, I. L. Zupp for his assistance with Expt 2, and Astra-Hässle, Mölndal for supplying the drugs and for their interest and support.

\section{References}

Allard EK, Johnson KJand Boekelheide K (1993) Colchicine disrupts the cytoskeleton of rat testis seminiferous epithelium in a stage-dependent manner Biology of Reproduction 48 143-153

Blakeney AB, Harris PJ, Henry RJ, Stone BA and Norris T (1982) Gas chromotography of alditol acetates on a high-polarity bonded-phase vitreous-silica column Journal of Chromotography 249 180-182

Blakeney AB, Harris PJ, Henry RJ and Stone BA (1983) A simple and rapid preparation of alditol acetates for monosaccharide analysis Carbohydrate Research 113 291-299
Bradford MM (1976) A rapid and sensitive method for the quantitation of microgram quantities of protein utilizing the principle of protein-dye binding Analytical Biochemistry $\mathbf{7 2} 248-254$

Colatsky TJ and Follmer CH (1990) Potassium channels as targets for antiarrhythmic drug action Drug Development Research 19 129-140

Davies RV, Main SJ, Laurie MS and Setchell BP (1978) The effects of long-term administration of either a crude inhibin preparation or an antiserum to $\mathrm{FSH}$ on serum hormone levels, testicular function and fertility of adult male rats Journal of Reproduction and Fertility Supplement 26 183-191

Ferrer J, Nichols CG, Makhina EN, Salkoff L, Bernstein J, Gerhard D, Wasson J, Ramanadham S and Permutt A (1995) Pancreatic islet cells express a family of inwardly rectifying $\mathrm{K}^{+}$channel subunits which interact to form G-protein-activated channels Journal of Biological Chemistry $\mathbf{2 7 0}$ $26086-26091$

Galil KAA and Setchell BP (1988) Effects of local heating of the testes on the concentration of testosterone in jugular and testicular venous blood of rats and on testosterone production in vitro. International Joumal of Andrology 11 $61-72$

Gray TJB and Gangolli SD (1986) Aspects of the testicular toxicity of phthalate esters Environmental Health Perspectives 65 229-235

Hinton BT and Keefer DA (1983) Evidence for protein absorption from the lumen of the semiferous tubules and rete of the rat testis Cell Tissue Research $230 \quad 367-375$

Hinton BT and Setchell BP (1993) Fluid secretion and movement. In The Sertoli Cell pp 249-267 Eds LD Russell and MD Griswold. Cache River Press, Clearwater, FL

Hinton BT, White RW and Setchell BP (1981) Concentrations of myo-inositol in the luminal fluid of the mammalian testis and epididymis Journal of Reproduction and Fertility $\mathbf{5 8} 395-399$

Jenkins AD, Lechene CP and Howards SS (1980) Concentration of seven elements in the intraluminal fluids of the rat seminiferous tubules, rete testis and epididymis Biology of Reproduction 23 981-987

Johnson KJ, Hall ES and Boekelheide K (1991) 2,5-Hexanedione exposure alters the rat Sertoli cell cytoskeleton. I. Microtubules and seminiferous tubule fluid secretion Toxicology and Applied Pharmacology $111432-443$

Kurachi $Y$ (1995) G protein regulation of muscarinic potassium channel American Journal of Physiology 269 C821-C830

Levine N and Marsh DJ (1971) Micropuncture studies of the electrochemical aspects of fluid and electrolyte transport in individual semiferous tubules, the epididymis and vas deferens in rats Journal of Physiology 213 557-570

Muniz ZM, Parcej CN and Dolly JO (1992) Characterization of monoclonal antibodies against voltage-dependent $\mathrm{K}^{+}$channels raises using a-dendrotoxin acceptors purified from bovine brain Biochemistry $\mathbf{3 1}$ $12297-12303$

Richburg LH, Redenbach DM and Boekelheide K (1994) Seminiferous tubule fluid secretion is a Sertoli cell microtubule-dependent process inhibited by 2,5-hexanedione exposure Toxicology and Applied Pharmacology 128 302-309

Ritzén EM, French FS, Weddington SC, Nayfeh SN and Hansson V (1974) Steroid binding in polyacrylamide gels; quantitation at steady state conditions Journal of Biological Chemistry $2496597-6604$

Ritzén EM, Hansson V and French FS (1981) The Sertoli cell. In The Testis pp 171-194 Eds H Burger and DM de Kretser. Raven Press, New York

Robinson R and Fritz IB (I979) Myoinositol synthesis by Sertoli cells, and levels of myoinositol biosynthetic enzymes in testis and epididymis Canadian Journal of Biochemistry $57962-967$

Russell LD, Sinha Hikim AP, Ettlin RA and Clegg ED (1990) Histological and Histopathological Evaluation of the Testis Cache River Press, Clearwater, FL

Setchell BP (1970) The secretion of fluid by the testes of rats, rams and goats, with some observations of the effects of age, cryptorchidism and hypophysectomy Journal of Reproduction and Fertility 23 79-85

Setchell BP and Brown BW (1972) The effect of metabolic alkalosis, hypotension and inhibitors of carbonic anhydrase on fluid secretion by the rat testis Journal of Reproduction and Fertility 28 235-240

Setchell BP and Main SJ (1975) The blood-testis barrier and steroids. In Hormonal Regulation of Spermatogenesis pp 223-233 Eds FS French, V Hansson, EM Ritzén and SN Nayfeh. Plenum Press, New York

Setchell BP, Hinton BT, Jacks F and Davies RV (1976) Restricted penetration of iodinated follicle-stimulating and luteinizing hormones into the semifierous tubules of the rat testis Molecular and Cellular Endocrinology 6 59-69

Setchell BP, Laurie MS, Main SJ and Goats GC (1978) The mechanism of transport of testosterone through the walls of the seminiferous tubules of the rat testis International Journal of Andrology Supplement 2 506-512 
Setchell BP, Tao L and Zupp JL (1996) The penetration of chromium-EDTA from blood plasma into various compartments of rat testes as an indicator of function of the blood testis barrier after exposure of the testes to heat Journal of Reproduction and Fertility 106 125-133

Tuck RR, Setchell BP, Waites GMH and Young JA (1970) The composition of fluid collected by micropuncture and catheterization from the semiferous tubules and rete testis of rats Pfluger Archiv fur der gesarnte Physiologie 318 225-243
Turner TT, Jones CE, Howards SS, Ewing LL, Zegeye B and Gunsalus GL (1984) On the androgen environment of maturing spermatozoa Endocrinology 115 1925-1932

Waites GMH and Gladwell RT (1982) Physiological significance of fluid secretion in the testis and blood-testis barrier Physiological Reviews 62 $624-671$ 